Tropical Journal of Pharmaceutical Research March 2019; 18 (3): 459-464

ISSN: 1596-5996 (print); 1596-9827 (electronic)

(C) Pharmacotherapy Group, Faculty of Pharmacy, University of Benin, Benin City, 300001 Nigeria.

\title{
Safranal induces autophagy by AMPK activation and protects neurons against amyloid beta in Alzheimer's disease
}

\author{
Xiaocheng Huang, Manlian Zhu, Ying Hua, Xiumei Yan, Ruilai Jiang \\ Department of Respiratory, Lishui Second Hospital, Lishui, Zhejiang, China
}

${ }^{*}$ For correspondence: Email: JosegCarterqa@yahoo.com; Tel/Fax: +86 5782559898

Sent for review: 20 October 2018

\begin{abstract}
Purpose: To investigate autophagic induction by stranal a n rop, tion a nst amyloid beta in Alzheimer's disease.

Methods: Primary neurons and SH-SY5Y cells were ed this st y. As sment of cell proliferation and neuroprotection by safranal against amyloid wa done 1 3 4,5-dimethylthiazol-2-yl)-2,5diphenyltetrazolium bromide (MTT) assay. AMPI act/ ion d minhibition were determined by western blot. Changes in intracellular calcium le l, reac ve o gen species (ROS) and mitochondrial membrane potential (MMP) were as esse rlo cytome

Results: Safranal protected $\eta$ 'vuro all al loid b toxicity. Furthermore, safranal activated AMPK pathway by activation fal $\mathrm{m} / \mathrm{call} d \mathrm{~d}$ dep hdent protein kinase (CaMKK $\beta$ ) to induce autophagy in both cell lir, Th Jxh indu d by yloid beta in primary neurons and SH-SYSY cells were attenuated y safra. Mo ver, a vloid beta-induced calcium levels were significantly decreased by safranal ile $\mathrm{SS}$ o $M \mathrm{M}$ loss puduced by amyloid beta was attenuated by safranal. Conclusion: $T$ se fin gs gge that gfranal protects neurons against amyloid beta by inducing autophagy via , TK $p$ hwa) The fore, safranal is a probable therapeutic target for Alzheimer's disease

Keywords Amy d be imary euronal cells, Autophagy, AMPK, LC3-II, Neuroprotection

This is an Open 2 article that uses a funding model which does not charge readers or their institutions for access and tributed under the terms of the Creative Commons Attribution License (http://creativecommuns.org/licenses/by/4.0) and the Budapest Open Access Initiative (http://www.budapestopenaccessinitiative.org/read), which permit unrestricted use, distribution, and reproduction in any medium, provided the original work is properly credited.
\end{abstract}

Tropical Journal of Pharmaceutical Research is indexed by Science Citation Index (SciSearch), Scopus, International Pharmaceutical Abstract, Chemical Abstracts, Embase, Index Copernicus, EBSCO, African Index Medicus, JournalSeek, Journal Citation Reports/Science Edition, Directory of Open Access Journals (DOAJ), African Journal Online, Bioline International, Open-J-Gate and Pharmacy Abstracts

\section{INTRODUCTION}

Alzheimer's disease $(A D)$ is a neurodegenerative disease which happens in old age [1]. The accumulation of amyloid beta and hyperphosphorylation of tau are the main pathological hall markers of $A D$ [2]. Senile plaque comprises amyloid beta protein which plays a role in progression and development of $A D$ [3].
Even though exact mechanism of amyloid beta induced toxicity remains obscure, few studies provide evidence that amyloid beta induced toxicity is mediated by loss of MMP and ROS [4].

Various reports show that oxidative stress is caused by extracellular amyloid beta which leads to the dysfunction of mitochondria [5]. Furthermore, it was shown by in vivo studies that amyloid beta leads to structural abnormalities 
that accumulated in the mitochondria of Alzheimer's disease brain [6]. Therefore, these events trigger the activation of apoptotic proteins and cytochrome $\mathrm{C}$ release from mitochondria [7]. Although there are four drugs available in the market that give symptomatic benefit, but there is no drug in the market that prevents Alzheimer's disease [8]. Efforts are being made by researchers to discover natural compounds that is potent inhibitors of neuronal loss and provides a neuroprotective role $[9,10,14]$. Natural products exert antioxidant potentials through various pathways of signal transduction $[11,12]$.

Safranal, a natural compound extracted from crocus sativas has an anticancer property [13]. Moreover, safranal has an antioxidant property as it scavenges free radical and protects against gastric cancer induced by indomethacin [14]. Safranal has been found to be cytotoxic against specific cancers and it has also been proved in animal model for anti- depressant property as well as slows down degeneration of photoreceptor $[15,16]$.

In this study, we have screened 500 natural compounds for neuroprotection agair amyloid beta in SH-SY5Y cells. Amnng all compounds, safranal has been pun $6 \mathrm{~b}$ neuroprotective against amy id $\mathrm{SH}-$ SY5Y cells. Interestingly, has br obs ved that activation of AMPK lea to he ibit of mTOR which furthe pads autophagic proteins.

\section{EXPERIMEN $A L$}

Dulbecco's Minimal $\mathrm{a}$ ential medium, transretinoic acid, BSA, Pericillin G, Streptomycin sulphate, MTT (3-(4,5-dimethylthiazol-2-yl)-2,5diphenyltetrazolium bromide), phosphate buffer saline (PBS), RIPA (Radioimmunoprecipitation assay buffer), Sodium pyruvate, safranal, $d$ glucose, rhodamine-123, amyloid beta AntiPhospho LKB1(1: 1000) and Anti-Phospho AMPK (1: 1000) were obtained from SigmaAldrich Fluo-3AM, HEPES, fetal bovine serum , L-15 media, neurobasal media, Glutamax, B27 was obtained from Invitrogen. Immobilon Western Chemiluminescent HRP substrate and PVDF membrane was obtained fromMillipore Anti-ATG7 (1: 1000), ATG12 (1: 1000), mTOR (1: 1000), LC3-II (1: 1000), SQSTM1 (1: 1000) and Anti-Actin (1: 1000) antibodies was from cell signalling technology (Suite 514 No. 1101 South Pu Dong Road, Shanghai, 200120). In all experiments we have used analytical grade reagents as well as chemicals.

\section{Cell culture}

Human neuroblastoma SH-SY5Y cells were purchased from ATCC and were cultured in DMEM with sodium pyruvate, glutamine, streptomycin, penicillin, 10\% FBS maintained with a humidified condition $95 \% \mathrm{O}_{2}$ with $5 \%$ $\mathrm{CO}_{2}$ at $37{ }^{\circ} \mathrm{C}$. Retinoic $(10 \mu \mathrm{M})$ with $5 \% \mathrm{FBS}$ were used for differentiation of SH-SY5Y cells.. For every two days media was decant and replaced with fresh media supplemented with 5 $\%$ FBS and $10 \mu \mathrm{M}$ retinoic acid. For drug treatments in case of neuroprote assay, cells at a confluence of $70 \%$ pro reated with safranal followed by amyl d ta tre tment at indicated time periods and co ce ration.

\section{Isolation of primary neur il Ils}

For isolation ma n ur cells Balb/c female mice vere acri afur 18 days of S station d api' an whole brain was is ate $n$ ice- d 15 media with $0.75 \%$ glu se $\mathrm{HF}$, $N 5 \mathrm{mM}, 100 \mathrm{mg} / \mathrm{L}$ $\mathrm{om}$ in a $0 \mathrm{mg} / \mathrm{L}$ penicillin. The disso atic of bram was done enzymatically with papain $(1 \mathrm{~g} / \mathrm{mL}$ ) in hibernated media in an cubat at $67^{\circ} \mathrm{C}$ for $30 \mathrm{~min}$. The brain sample $s$ tar $\mathrm{d}$ d every $10 \mathrm{~min}$. The cells were passed th fire coated pipette to make cell suspension. Cells were resuspended into eurobasal media and were passed through cell strainer $40-\mu \mathrm{m}$ in order to remove cell debris. Cells at a density of $\sim 106$ were seeded into each 6 well of poly-l-lysine coated 6 well plates. For every day half of the media was decanted and replaced with fresh neurobasal media until the culture period ends.

\section{Neuroprotection and cell viability assay}

Neuroprotection assay was performed by MTT assay in which differentiated SH-SY5Y cells and primary neurons were grown in 96 well plates and were pre-treated with safranal for $24 \mathrm{~h}$ at a concentration of $5,10,20,40,60,80$ and 100 $\mu \mathrm{M}$ followed by amyloid beta $(20 \mu \mathrm{M})$. Therefore the total treatment is for $48 \mathrm{~h}$. Before $4 \mathrm{~h}$ of termination of experiment MTT was added and media were decanted followed by DMSO (150 $\mu \mathrm{L})$ into each well. Absorbance was taken on a plate reader at $570 \mathrm{nM}$. Cell viability assay was performed by MTT assay, in which differentiated SH-SY5Y cells and primary neurons were grown in 96 well plates. These cells were treated with safranal at a concentration of 1, 5, 10, 20, 40, 60, 80 and $100 \mu \mathrm{M}$ for $48 \mathrm{~h}$ and $72 \mathrm{~h}$. Before $4 \mathrm{~h}$ of termination of experiment, MTT were added as above in neuroprotection assay. 


\section{Western blot}

Differentiated SH-SY5Y cells and primary neurons were treated with safranal at a concentration of 5, 10 and $20 \mu \mathrm{M}$ for $48 \mathrm{~h}$. These Cells were lysed with RIPA buffer containing $2 \%$ protease inhibitor cock tail, $150 \mathrm{mM} \mathrm{NaCl} 1 \mathrm{mM}$ Na3VO4, $5 \mathrm{mM}$ EDTA, 1mM PMSF for $45 \mathrm{~min}$ in ice and vortexed for every $10 \mathrm{~min}$. Lysed cells were centrifuged at $1600 \mathrm{~g}$ for $15 \mathrm{~min}$ and supernatant containing proteins were collected followed by protein estimation by Bradford method. Protein loading dye (2X) was added to each protein sample.

Protein samples of $70 \mu \mathrm{g}$ were loaded into each well of SDS PAGE and were run for $3 \mathrm{~h}$ at $85 \mathrm{~V}$; the gels were transferred into PVDF membranes for $2 \mathrm{~h}$ at $100 \mathrm{~V}$. Protein membranes were blocked with skimmed milk for $1 \mathrm{~h}$ at room temperature.. Primary antibodies were added overnight to each protein membrane at $4{ }^{\circ} \mathrm{C}$ followed by three times TBST washing for $5 \mathrm{~min}$ and secondary antibodies were added into membrane at room temperature for $1 \mathrm{~h}$. Blots were incubated with Millipore Immobilon western chemiluminescent HRP substrate, before being analyzed for signal on either $\mathrm{x}$-ray film or chemidoc system.

\section{Determination of intracellular calciu lever \\ Human neuroblastoma $\mathrm{SH}_{-} \mathrm{Y}$ 5} grown for indicated time pe ocs in vell ates. Safranal were pre-treate to $c$ is a concentration of 5,1 and $2 \mu \mathrm{h}$ for $\mathrm{h}$. , ter $24 \mathrm{~h}$, amyloid beta $\mathrm{uM}$ ) as d dec ells or 24 h. i.e. total treatn in $\mathrm{fo} 48$ Ce yere treated with $\mathrm{F} / 3 \mathrm{~A}$ (e $\mu$ ) for 0 mIn into each well at $3,{ }^{\circ} \mathrm{C}$, llow y cen rifugation. Unbound dye $w$ move by three times washed with incomp te DMEM redia and these cells were re-suspen in DMEM incomplete media and subjected flow cytometer (BD FACS Calibur BD Biosciences, San Jose, California) to measure FLU $3 A$ dye fluorescence intensity bound to calcium.

\section{Measurement of reactive oxygen species level}

Differentiated SH-SY5Y cells were pre-treated with safranal at a 5,10 and $20 \mu \mathrm{M}$ followed by amyloid beta at a concentration of $30 \mu \mathrm{M}$ for a further $24 \mathrm{~h}$. DCFHDA at a concentration of 10 $\mu \mathrm{M}$ was added into each well for 30 min before termination of experiment. Cells were washed and trypsinized and centrifuged at $400 \mathrm{~g}$ for 5 min. Further, cells were re-suspended into PBS and were subjected to flow cytometer (BD FACS
Calibur BD Biosciences, San Jose, California) to measure florescence intensity of DCFHDA dye.

\section{Analysis of mitochondrial membrane potential}

MMP was monitored by flow cytometer by using JC-1. Briefly, differentiated SH-SY5Y cells were treated with safranal at a concentration of 5, 10 and $20 \mu \mathrm{M}$ were added into each well for $48 \mathrm{~h}$ and amyloid beta for $24 \mathrm{~h}$ in presence and absence of safranal. JC-1 dye was added was added $30 \mathrm{~min}$ before termination of the experiment. Cells were washed with PBS and were analyzed by flow cytometry (BD FACS Calibur).

\section{Statistical analysis}

Data are presented as mear \pm ( $n$ ). Statistical analysis was d b) Stu ents' thest and differences wo $c$ i de ed atistically significant at ${ }^{*} p-0$. 0101 or ${ }^{* * *} p<$ 0.005 . Origin a d (SPSS, Inc. Chicago, IL, USA wert sed for statistical

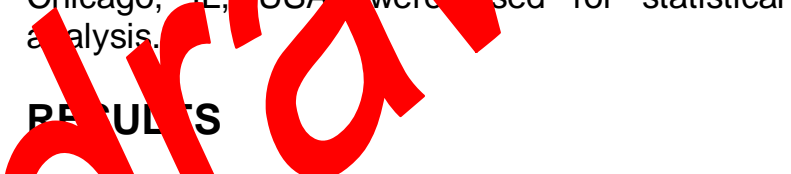

Safra I p tects SH-SY5Y cells and primary eurol $c \in s$ against amyloid beta

hore, safranal protected SH-SY5Y cells and primary neuronal cells at concentrations of 5 , $0,20,40$ and $60 \mu \mathrm{M}$ against amyloid beta induced toxicity as the viability of cells treated with safranal only increased for $48 \mathrm{~h}$ (Figure $1 \mathrm{~A}$ ). Moreover, the viability of cells remains constant after $20 \mu \mathrm{M}$. Furthermore, toxicity of safranal was not found at $1,5,10,20,40,60,80$ and $100 \mu \mathrm{M}$ concentrations at $48 \mathrm{~h}$ in differentiated SH-SY5Y and primary neuronal cells (Figure $1 \mathrm{~B}$ ).

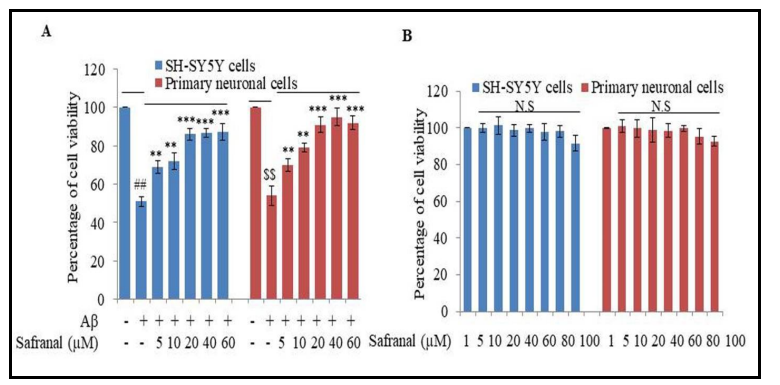

Figure 1: Effect of safranal on amyloid beta induced toxicity in SHSY5Y cells and primary neuronal cells. (A-B) Differentiated SH-SY5Y cells and primary neurons were treated with safranal at a concentration of $5,10,20,40$ and $60 \mu \mathrm{M}$ followed by amyloid beta treatment for $48 \mathrm{~h}$. MTT assay was determination for cell proliferation; $n=3$ 


\section{Safranal induces autophagy by activating AMPK pathway}

Differentiated SH-SY5Y cells and primary neurons were treated with safranal at 5,10 and $20 \mu \mathrm{M}$ for $48 \mathrm{~h}$. The expression level of LKB1 remained constant in safranal $(5,10$ and $20 \mu \mathrm{M})$ treated cells compared with untreated cells. Interestingly, the expression of CaMKK $\beta$ was gradually increased with increased concentration of safranal $(5,10$ and $20 \mu \mathrm{M})$ for $48 \mathrm{~h}$. Furthermore, CaMKK $\beta$ promoted phosphorylation of AMPK at thr-172 which led to the inhibition of mTOR. Therefore, inhibition of mTOR leads to the activation of autophagy which was evident by the expression of LC3-11 level and down regulation of SQSTM1. The expression of other autophagic proteins like ATG7 and ATG12 were increased in cells by safranal at 5, 10 and $20 \mu \mathrm{M}$ for $48 \mathrm{~h}$ (Figure $2 \mathrm{~A}$, B). Thus, safranal activates AMPK by CaMKK $\beta$ which further induces autophagy through mTOR inhibition.
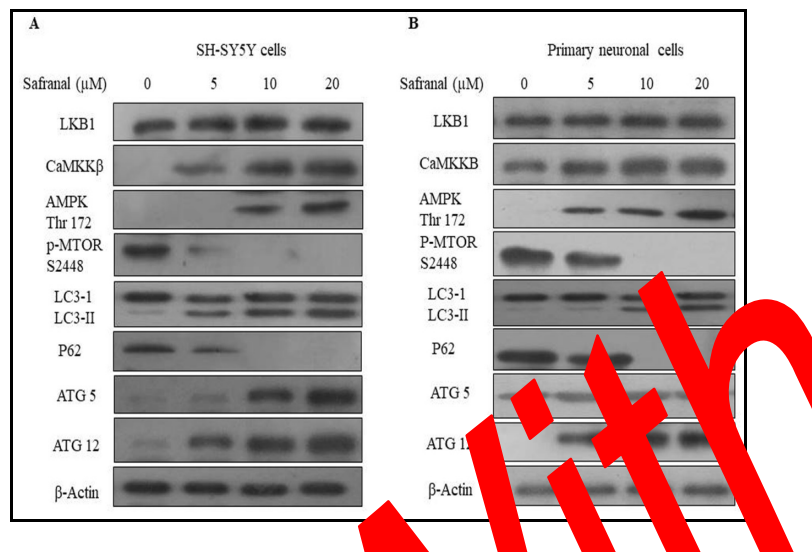

Figure 2: Safranal ind to aut hagy by activation. (A, B) ferent ed $\mathrm{H}-\langle 5 \mathrm{Y}$ o primary
neuronal cells were eated with
10 a $20 \mu \mathrm{M}$ neuronal cells were eatec with
for $48 \mathrm{~h}$ in which the res on or
$\mathrm{KK} \beta$ increased which leads to the activ on f $p$-AM (Thr 172) and inhibition of $p$-MTOR ( $\$ 4$ while ne autophagic marker LC3-II lipidation observed and P62 degradation takes place in S. Y5Y cells and primary neuronal cells

\section{Safranal attenuates intracellular calcium level induced by amyloid beta in SH-SY5Y cells}

Amyloid beta increases the intracellular calcium level of the cells which further leads cells towards death. Based on then neuroprotection data, we hypothesised that safranal can reduce the intracellular calcium level induced by amyloid beta. Cells were pre-treated with safranal at 5,10 and $20 \mu \mathrm{M}$ for $24 \mathrm{~h}$ and after $24 \mathrm{~h}$ amyloid beta was added in the presence and absence of safranal at 5, 10 and $20 \mu \mathrm{M}$. Surprisingly, intracellular calcium levels were decreased with co-treated cells (amyloid beta and safranal) compared with amyloid beta alone as shown through flow cytometer (Figure 3). Safranal at a concentration of 5,10 and $20 \mu \mathrm{M}$ decreased relative fluorescence intensity which was increased by amyloid beta alone.

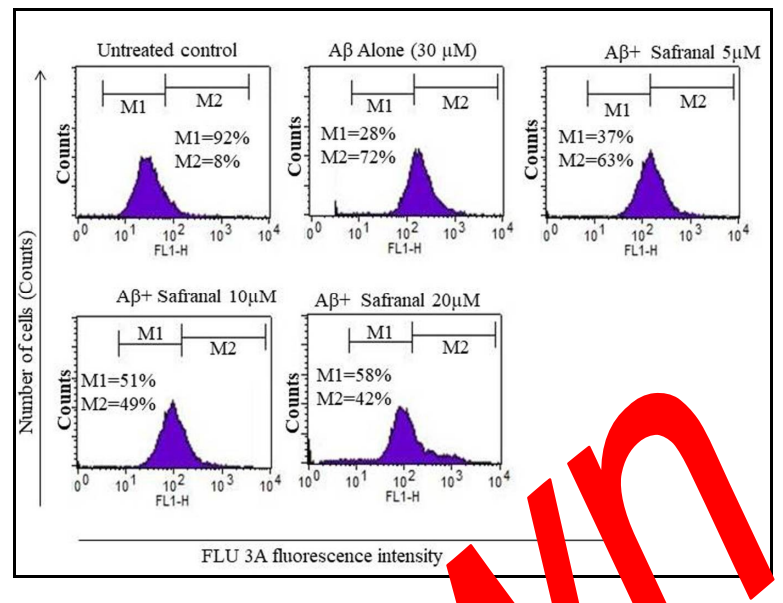

Figure 3: Effect of safra of th ac llula alcium level in SH-SY5Y nolls. ntr el calcrum is elevated by amyl ta ic is creased by safranal at a con ntrat dep ent manner for 48 h. Ir racellul? a um was tected by FLU-3A dye aco ntratio i 5 ; $n=3$

$\mathrm{Re} 0$ gen ars elevated by amyloid $b$ a is atte uateo- oy safranal in SH-SY5Y c Is

Am oid $\mathrm{Ma}$ elevated the reactive oxygen bec. a concentration of $30 \mu \mathrm{M}$ which was c reased by safranal at a concentration of 5, 10 an $20 \mu \mathrm{M}$ for $48 \mathrm{~h}$ in SH-SY5Y cells (Figure 4). Safranal decreases the relative fluorescence intensity of DCFHDA dye which was increased by amyloid beta as observed by flow cytometer. Therefore it is clearly evident from the results that reactive oxygen species generated by amyloid beta is attenuated by safranal.

\section{Safranal increased mitochondrial membrane potential after exposure of Amyloid beta in SH-SY5Y cells}

Amyloid beta decreased the mitochondrial membrane potential of SH-SY5Y and primary brain neuronal cells which was attenuated by safranal at concentrations of $5 \mu \mathrm{M}, 10 \mu \mathrm{M}$ and 20 $\mu \mathrm{M}$. The relative fluorescence intensity ofrhodamine 123 was decreased in amyloid beta treated cells which were further increased by safranal as evaluated by flow cytometer (Figure $5)$. Therefore, these results are clear evidence that mitochondrial membrane potential loss by amyloid beta is attenuated by safranal. 


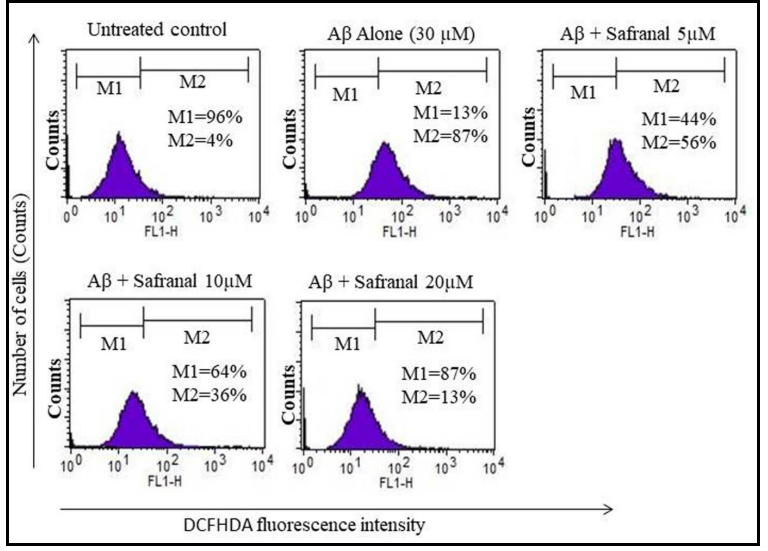

Figure 4: Effect of safranal on reactive oxygen species induced by amyloid beta in SH-SY5Y cells. The reactive oxygen species generated by amyloid beta was reduced by safranal at a concentration of 5 , 10 and $20 \mu \mathrm{M}$ for $48 \mathrm{~h}$. DCFDA at a concentration of $20 \mu \mathrm{M}$ was used to capture the fluorescence through flow cytometer; $n=3$

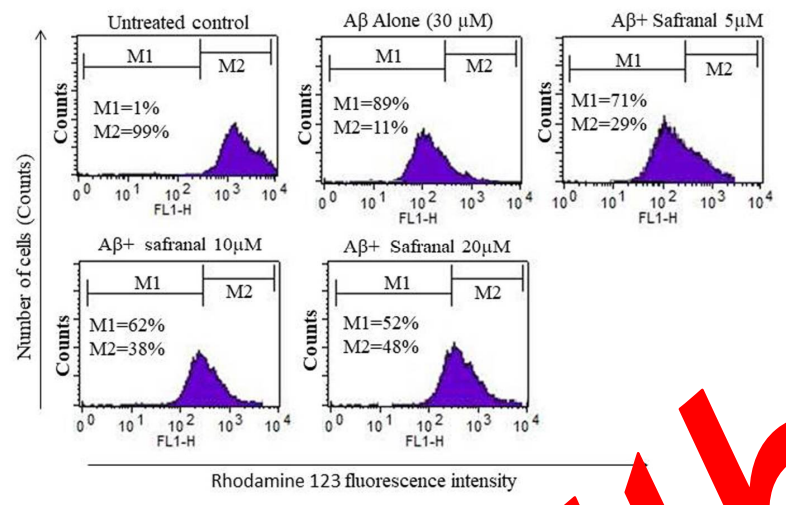

Figure 5: Mitochondrial membrane amyloid beta is attenuated by safr cells. Loss of mitochondrial nembr amyloid beta was attenuater safra $20 \mu \mathrm{M}$ for $48 \mathrm{~h}$. Rhodamine a ncen ation $500 \mathrm{nM}$ was used r 45 niो and fluor cence intensity was captured, flow tom of $\mathrm{P}=3$

\section{DISCUSSION}

Crocus sativus (saffron) is $d$ for colour and taste as a food additive across the world [17]. It is a well-established fact that saffron has anticancer activity in vitro and in vivo against various cancers [18]. It has been shown that saffron has neuroprotective effect in various neurodegenerative diseases [19]. Safranal, a natural compound derived from Crocus sativus, has shown notable anti-cancer activity both in vivo and in vitro in tissue cultures [18]. Over the past years, it has been shown that safranal plays various roles in neurodegenerative diseases by providing neuroprotection via various mechanisms such as anti-apoptotic, edema attenuating and anti-inflammatory activities in a rat model of traumatic injury [20,21].

Safranal has been proposed as a potent antioxidant agent that affords cytoprotection [22]. It has been reported for the first time in this study that AMPK is activated by CaMKK $\beta$ in safranal treated SH-SY5Y and primary cells. Furthermore, AMPK activation leads to the inhibition of mTOR which further leads to autophagic induction as shown by the autophagic marker, LC3-II and P62. The results also showed that safranal attenuates the mitochondrial membrane potential loss induced by amyloid beta but decreases the reactive oxygen species induced by amyloid beta. Furthermore, safranal protected SH-SY5Y cells against amyloid beta toxicity. Therefore, safranal should be further investigated as a potent therapeutic target in Alzheimer's di

\section{CONCLUSION}

Amyloid beta is a well-estab ed heu toxin which generates reactive xyg ho cies, and increases calcium levenna ss f chondrial membrane poten' tim lo ling to neuronal cell doat Saf hal pects neuronal cells gainat anylo axicity which ultimate $r$ ices OS, alcium level and mitochn rial nemk ne potential loss. The neur sro tion provic sy safranal occurs via AMI path ay rainst beta amyloid. Therefore, afre al me be suitable for use in clinical $\mathrm{ct}$ to vide protection against amyloid be in 'ab mer's disease.

\section{DE -ARATIONS}

\section{lcknowledgement}

Finance assistance under Grant no BDM 1570215 was provided by National Natural Science Foundation of China.

\section{Conflicts of interest}

No conflict of interest is associated with this work.

\section{Contribution of authors}

We declare that this work was done by the authors named in this article and all liabilities pertaining to claims relating to the content of this article will be borne by the authors. Xiaocheng Huang designed all the experiments and revised the manuscript. Zanlian Zhu and Ying Hua performed the experiments, Xiumei Yan 
designed flow cytometer experiments. Ruilai Jiang designed and wrote the manuscript.

\section{REFERENCES}

1. Johnson IP. Age-related neurodegenerative disease research needs aging models. Front Aging Neurosci. 2015; 7: 168.

2. Huang HC, Jiang ZF. Accumulated amyloid- $\beta$ peptide and hyperphosphorylated tau protein: relationship and links in Alzheimer's disease. J Alzheimers Dis. 2009; 16(1): 15-27.

3. Sadigh-Eteghad S, Sabermarouf B, Majdi A, Talebi M, Farhoudi M, Mahmoudi J. Amyloid-beta: a crucial factor in Alzheimer's disease. Med Princ Pract. 2015; 24(1): 110.

4. Du H, Guo L, Yan S, Sosunov AA, McKhann GM, Yan SS. Early deficits in synaptic mitochondria in an Alzheimer's disease mouse model. Proc Natl Acad Sci USA. 2010; 107(43): 18670-18675.

5. Mao P, Reddy PH. Aging and amyloid beta-induced oxidative DNA damage and mitochondrial dysfunction in Alzheimer's disease: implications for early intervention and therapeutics. Biochim Biophys Acta. 2011; 1812(11): 1359-1370.

6. Reddy PH. Amyloid beta, mitochondrial structural and functional dynamics in Alzheimer's disease. Exp Neurol. 2009; 218(2): 286-292.

7. Santos RX, Correia SC, Wang X, Perry G, Smith MA, Moreira PI, Zhu X. Alzheimer's disease: diverse aspects of mitochondrial malfunctioning. Int J Clin Exp Pathol. 2010; 3(6): 570.

8. Cummings J, Lee G, Mortsdorf T, Ritter A, Zhong Alzheimer's disease drug development eline Alzheimers Dement. 2017; 3(3): 367-384

9. Bagli E, Goussia A, Moschos MM, Agna Natural compounds and neuroprotecti of action and novel delivery 30(5): 535-547.

10. Essa MM, Vijayan RK astella -G alt $G, N_{1}$ on 22. MA, Braidy N, Guillemi iJ. $N$ ropr a e effed of natural products again heim disease. Neurochem Res. 2012; 37(9). 22. 1842.

11. Ng TB, Liu F, Wang ZT. Antiox products from plants. Life Sci. $200 \mathrm{u}$ (8): 709-723.
12. Nogueira CC, Paixão IC, Teixeira VL. Antioxidant activity of natural products isolated from red seaweeds. Nat Prod Commun. 2014; 9(7): 1031-1036.

13. Mardani H, Sekine T, Azizi M, Mishyna M, Fujii Y. Identification of safranal as the main allelochemical from saffron (Crocus sativus). Nat Prod Commun. 2015; 10(5): 775-777.

14. Samarghandian S, Azimi-Nezhad M, Samini $F$. Preventive effect of safranal against oxidative damage in aged male rat brain. Exp Anim. 2015; 64(1): 65-71.

15. Khazdair MR, Boskabady MH, Hosseini M, Rezaee R, Tsatsakis AM. The effects of Crocus sativus (saffron) and its constituents on nervous system: A review. 2015; Avicenna J Phytomed. 5(5): 376.

16. Fernandez-Sánchez L, Lax P, Esquiva G, Martín-Nieto J, Pinilla I, Cuenca N. Safranal, a saffron constituent, attenuates retinal degeneration in $\mathrm{P} 23 \mathrm{H}$ rats. $\mathrm{PLOS}$ One. 2012; 7(8): e43074.

17. Milajerdi A, Djafarian K, Hosseini B. The toxic saffron (Crocus sativus L.) and its constituent yains normal and cancer cells. J Cell Biochem. 10 : 2332.

18. Samarghandian S, Shoshtari ME Sar Izae J, Hossinimoghadam H, Farahze JA. , th un ract, of safranal against neurahiasto ce s. macoyn Mag. 2014; 10(2): S41

19. Fernandez-Sánchez L Lax Noalı A, Angulo A, Maned Cur M.Nat a npound, from saffron and $b$ r b preve vis loss and retinal degepm n. $M$ ecules, Q(8) B875-13893.

20. Sam gham o Sarm F, Azimi-Nezhad $M$, Fal ondeh $A$ oxidative effects of safranal on imm vilization duc oxidative damage in rat brain. sun i Lett, 7; 659: 26-32.

21. Zh g C, Fan L, Zou Y, Dang $X$, Wang $K$, Song J. $\mathrm{Ne}$ protective effects of safranal in a rat model of trau atic injury to the spinal cord by anti-apoptotic, antiinflammatory and edema-attenuating. Tissue Cell. 2015; 47(3); 291-300.

2. Nassiri-Asl M, Hosseinzadeh H. Neuropharmacology effects of saffron (Crocus sativus) and its active constituents. In: Bioactive Nutraceuticals and Dietary Supplements in Neurological and Brain Disease; 2015; pp 29-39. 